JOTE Volume 2 Nomor 1 Tahun 2020 Halaman 49-58

JOURNAL ON TEACHER EDUCATION

Research \& Learning in Faculty of Education

\title{
Penerapan Model Pembelajaran Talking Stick Game untuk Meningkatan Motivasi dan Hasil Belajar Siswa pada Materi Organ Gerak Hewan Kelas V SD Negeri Dendeng Tahun Pelajaran 2018/2019
}

\author{
Yana Fansita Taopan \\ SD Negeri Dendeng, Kec. Kupang Tengah, Kab. Kupang, NTT \\ Email : yana.taopan80@gmail.com
}

\begin{abstract}
Abstrak
Tujuan penelitian ini untuk meningkatkan motivasi dan hasil belajar siswa dengan menggunakan model talking stick game. jenis penelitian tindakan kelas model spiral dari Kemmis dan Taggart (R.Wiriaatmaja, 2009:66) di mana setiap siklus dilaksanakan empat tahap yaitu perencanaan (plan), tindakan (act), pengamatan (observ), dan refleksi (reflect). Hasil penelitian menunjukkan bahwa pada siklus I rata-rata nilai yang diperoleh siswa $69,58 \%$ kemudian pada siklus II dengan nilai rata-rata $80,69 \%$. Penggunaan model talking stick game dapat meningkatkan motivasi dan hasil belajar siswa dengan rata-rata siklus I $69,58 \%$ dan siklus II 80,69 . Motivasi siswa pada siklus I rata-rata $83 \%$. Sedangkan pada siklus II rata-rata nilai angket di kelas $\mathrm{V}$ 95\%. Ini menunjukkan dengan model talking stick game ini sangat berpengaruh unutk meningkatkan motivasi siswa dalam melakukan pemebalajaran.
\end{abstract}

Kata kunci: Talking Stick Game, Motivasi dan hasil Belajar, Organ Gerak Hewan.

\begin{abstract}
The purpose of this study was to improve student motivation and learning outcomes by using the talking stick game model. This type of classroom action research is a spiral model from Kemmis and Taggart (R. Wiriaatmaja, 2009: 66) in which each cycle is carried out in four stages, namely planning (plan), action (act), observation (observ), and reflection (reflect). The results showed that in the first cycle the average value obtained by students was $69.58 \%$, then in the second cycle, the average value was $80.69 \%$. The use of the talking stick game model can improve student motivation and learning outcomes with an average cycle I $69.58 \%$ and cycle II 80.69. Student motivation in cycle I averaged $83 \%$. While in cycle II the average value of the questionnaire in class $\mathrm{V}$ was $95 \%$. This shows that the talking stick game model is very influential in increasing students' motivation to do learning.
\end{abstract}

Keywords: Talking Stick Game, Motivation and Learning Outcomes, Animal Organs. 


\section{PENDAHULUAN}

Pendidikan di Indonesia saat ini menjadi salah satu sektor yang menjadi perhatian utama pemerintah. 20\% APBN dikhususkan untuk meningkatkan kualitas dan mutu pendidikan. Banyak perubahan yang terjadi seiring perkembangan tekhnologi dan informasi Pemerintah melalui kementrian pendidikan dan kebudayaan tengah berusaha mempersiapkan generasi masa depan yang mampu menghadapi tentangan era revolusi industri 4.0. guru yang professional dan efektik adalah guru yang mampu mempersiapkan generasi unggul yang siap mengadapi tantangan artificial intelegen tersebut,suatu masa di mana akan muncul kecerdasan buatan yang akan menggantikan peran manusia. perubahan kurikulum tingkat satuan pendidikan tahun 2006 menjadi kurikulum 2013 merupakan salah satu kebijakan pemerintah untuk menjawab tantangan tersebut.

Kurikulum 2013 yang berbasis karakter di sekolah dasar dengan muatan berbagai mata pelajaran, siswa dituntut selain memahami materi juga mampu berdiskusi dan disiplin serta mampu memecahkan masalah yang ada di lingkungan sekitar sebagai wujud penerapan pengetahuan yang diperoleh. Agar dapat terwujud harapan tersebut maka guru dengan berbagai metode pembelajaran berupaya mengimplementasikan dalam proses pembelajaran di kelas dengan memperhatikan karakteristik kemampuan dan gaya belajar siswa. Hal tersebut dapat terlihat pada minat siswa terhadap mata pelajaran tertentu.

Ilmu pengetahuan alam sebagai ilmu yang mempelajari tentang gejala dan hukum alam, yang saat ini dilaksanakan secara terpadu sesuai dengan permendiknas No 22 tahun 2006, dalam mempelajarinya, siswa perlu dibimbing agar dapat mempelajari alam sesuai dengan gaya belajar masing-masing. Peneliti sebagai guru kelas dengan berbagai metode pembelajaran diterapkan salah satunya dengan metode cooperative learning digunakan peneliti sebagai guru kelas $\mathrm{V}$ (lima) SDN Dendeng untuk meningkatkan kemampuan siswa memahami fungsi "Organ Gerak Hewan " Mata Pelajaran IImu Pengetahuan Alam. Untuk mengukur pengetahuan siswa terhadap materi pembelajaran maka pada akhir pembelajaran guru melakukan evaluasi. Berdasarkan hasil evaluasi terdapat 6 siswa yang memperoleh nilai 70, 11 siswa memperoleh nilai 50, 6 siswa memperoleh nilai 45 dan 5 siswa memperoleh nilai 40 . Data pendukung lain untuk mengukur sikap siswa adalah hasil pengamatan peneliti selama proses pembelajaran nampak banyak siswa yang tidak terlibat dalam diskusi dan juga banyak siswa yang saling mengganggu pada saat pembelajaran berlangsung.

Berdasarkan hasil refleksi, percakapan dengan teman sejawat dan identifikasi gaya belajar siswa dan serta telaah sumber-sumber yang relevan dengan masalah yang dihadapi maka peneliti memilih "talking stick game" sebagai salah satu bentuk metode permainan untuk merangsang minat belajar siswa. Hal tersebut sejalan dengan pendapat Muhamad Anwar (2018:145) yang menyatakan: tujuan utama game method atau metode permainan adalah untuk menciptakan kesenangan dan ketertarikan akan proses pembelajaran karena metode ini mengurangi sifat kelas yang monoton dan membosankan serta menciptakan kesenangan dan daya tarik kelas secara penuh. 
Pendapat Anwar di atas dipertegas oleh Horward Gardner (2001), dalam Muhamad Anwar (2018:) yang menyatakan bahwa: "Gaya belajar siswa tercermin dari kecendrungan jenis kecerdasan yang dimiliki siswa tersebut. artinya , jika seorang siswa memiliki kecendrungan kecerdasan visual spasial maka gaya belajarnya akan ditunjukan dengan banyak mengingat apa yang dilihat dari pada apa yang didengar, senang membaca daripada dibacakan, senang menggambar dan mendesain, serta senang berdemostrasi daripada ceramah".

Menurut Lester D.Crow dan Alice Crow (1958) dalam A.Fauziah,A.Rosnaningsih,dan S.Ashar (2017 :4) belajar adalah perolehan kebiasaan ,pengetahuan dan sikap termasuk cara baru untuk melakukan sesuatu dan upaya seseorang untuk mengatasi kendala atau menyesuaikan situasi yang baru. Slameto (dalam Gullam Hamdu, Lisa Agustina 2011:2) berpendapat belajar merupakan serangkaian kegiatan jiwa raga untuk memperoleh suatu perubahan tingkah laku sebagai hasil dari pengalaman individu dalam interaksi dengan lingkungan menyangkut aspek kognitif, afektif dan psikomotor.

Menurut Dimyanti (2002) dalam F.Daud (2012: 6) Motivasi dipandang sebagai dorongan mental yang menggerakan dan mengaarahkan perilaku manusia termasuk perilaku belajar. Sejalan dengan pendapat Dalyono (1996) dalam F Daud (2012 : 6) motivasi adalah daya penggerak atau pendorong untuk melakukan sesuatu pekerjaan yang berasal dari dalam dan luar diri seseorang.

Dua pendapat di atas membuktikan, bahwa metode game merupakan salah satu metode yang dapat memotivasi siswa untuk mengikuti pembelajaran di kelas dan meminimalisir tingkat kejenuhan siswa dan lebih dri itu diharapkan hasil belajar siswa dapat mengalami peningkatan. salah satu dari sekian banyak gaya belajar yang dimiliki siswa perlu diidentifikasi oleh guru agar dapat menerapkan metode atau pendekatan yang tepat. .ketika guru telah mengetahui gaya belajar siswa maka sangat mudah bagi guru menerapkan gaya mengajar. Melalui talking stick game diharapakan peran serta guru dan siswa dapat kelihatan tujuan pembelajaran dapat tercapai. Mengingat siswa sekolah dasar kususnya kelas $\mathrm{V}$ masih berada pada tahapan berpikir sistematik terhadap halhal yang konkrit maka penerapan game method talking stick diharapkan dapat menarik minat dan hasil belajar siswa.

\section{METODE}

\section{Seting Penelitian}

Penelitian ini dilakukan di SD Negeri Dendeng kecamatan Kupang Tengah Kabupaten Kupang. Waktu pelaksanaan pada bulan Juli s.d Agustus 2018 yang menjadi subjek penelitan adalah siswa kelas $\mathrm{V}$ tahun pelajaran 2018/2019 dengan jumlah siswa 21 orang, laki-laki 10, perempuan 11 orang.

\section{Desain Penelitian}

Penelitian yang dilaksanakan adalah jenis penelitian tindakan kelas model spiral dari Kemmis dan Taggart (R.Wiriaatmaja, 2009:66) dimana setiap siklus dilaksanakan empat tahap yaitu perencanaan (plan), tindakan (act), pengamatan (observ), da refleksi (reflect). Penelitian model Kemmis dan Taggart dapat digambarkan sebagai berikut: Penelitian dilaksanakan paling sedikit dua siklus. 
satu siklus terdiri dari empat tahapan yaitu perencanaan, pelaksanaan ,observasi dan refleksi dan setiap siklus dilaksanakan dua pertemuan. Empat tahapan tersebut dapat dijabarkan sebagai berikut:

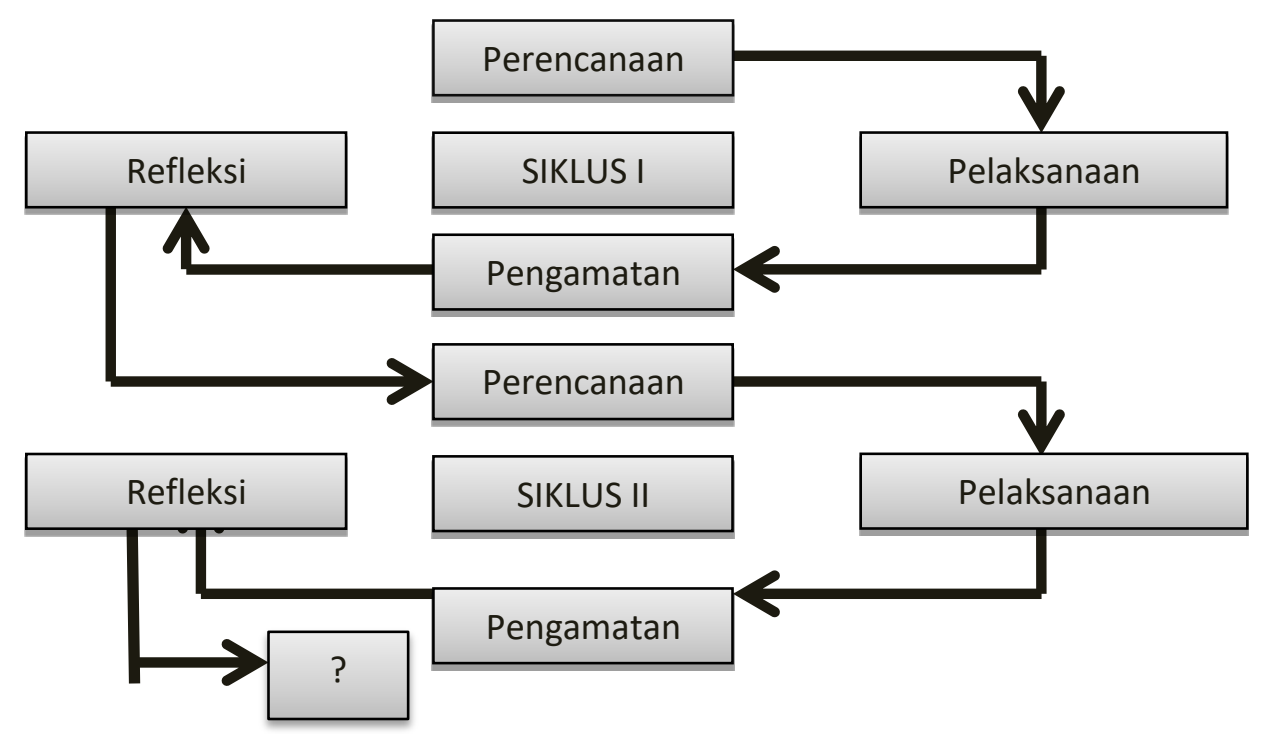

Gambar 1. Desain Penelitian Kemmis-Taggart (Arikunto, 2010:16)

\section{Perencanaan}

Pada tahapan perencanaan, peneliti menyiapkan rencana pelaksanaan pembelajaran (RPP) dengan mengacu pada silabus dan menyusun instrument penelitian. Permasalahan penelitian difokuskan pada motivasi belajar siswa terhadap materi organ gerak hewan mata pelajaran IPA. Peneliti menyiapkan rangkuman materi dan merancang skenario tindakan talking stick game untuk menigkatkan motivasi siswa pada materi organ gerak hewan mata pelajaran IPA.

\section{Pelaksanaan}

Pada kotak tindakan, dimulai pelaksanaan talking stick game dan pelaksanaannya sesuai dengan urutan dalam RPP yang terdiri dari pembukaan, kegiatan inti dan penutup.

a. Pengamatan

Pengamatan dilakukan oleh observer (pengamat) teman sejawat dengan berpedoman pada lembar pengamatan. Objek pengamatan yaitu guru dan siswa. Pengamat mengamati langkah-langkah proses pembelajaran yang dilakukan oleh peneliti (guru) dan aktifitas siswa dalam pembelajaran sesuai dengan RPP.

b. Refleksi

Pada tahapan refleksi, peneliti (guru) dan pengamat berdiskusi terkait tindakan yang telah dilaksanakan. Menginventarisir kekurangan-kekurangan yang dilakukan peneliti untuk diperbaiki pada siklus berikutnya.

Pengumpulan Data

Teknik yang digunakan untuk mengumpulkan data adalah sebagai berikut

a. Pengamatan digunakan oleh teman sejawat sebagai pengamat untuk mengamati langkah-langkah pembelajaran yang dilakukan oleh peneliti 
(guru). Instrument yang digunakan adalah lembar pengamatan yang dilakukan pada setiap pertemuan yang terdiri dari satu siklus. Dan terdapat 2 pertemuan untuk dua siklus.

b. Angket

Pengisian angket oleh siswa untuk mengetahui motivasi belajar siswa terhadap materi organ gerak hewan dengan menggunakan metode talking stick game. siswa mengisi dua kali angket.

\section{Analisis Data}

Data yang sudah terkumpul selanjutnya dikelompokan menjadi tiga jenis yaitu data pengelolaan pembelajaran, data motivasi belajar siswa dan data hasil belajar siswa. Pengelolaan pembelajaran diamati dengan lembar pengamatan yang terdiridari aspek-aspek yang diamati. Setap aspek aspek mendapatkan skor 0 atau 1. Skor 0 jika suatu langkah pembelajaran tidak dilaksanakan dan jika dilaksanakan mendapatkan skor 1 .

Nilai pengelolaan pembelajaran dapat dihitung sebagai berikut :

$N \frac{S}{S \max } x 100$

$\mathrm{N}$ : nilai pelaksanaan pembelajaran

$S$ : skor pelaksanaan pembelajaran

$S$ Mas : skor maksimum pelaksanaan pembelajaran

Predikat nilai pelaksanaan pembelajaran :

$N \leq 70$ : kurang

$70<\mathrm{N} \leq 80$ : Cukup

$80<\mathrm{N} \leq 90:$ Baik

$90<\mathrm{N} \leq 100$ : Sangat baik.

\section{Analisis Motivasi Belajar}

Motivasi belajar siswa diperoleh dari angket yang telah diisi oleh siswa. Di dalam angket terdiri dari aspek-aspek yang dinilai. Setiap aspek diukur dengan mengisi pernyataan sangat setuju (SS), setju (S), tidak setuju (TS), Sangat tidak setuju (STS). Kemudian jawaban itu dikonversi menjadi bentuk kuantitatif yaitu 4,3,2,1 seperti tabel di bawah ini:

Tabel 1. Indikator Motivasi Siswa

\begin{tabular}{ll}
\hline Kategori pendapat & Skor \\
\hline SS (sangat setuju) & 4 \\
\hline S (setuju) & 3 \\
\hline TS (tidak setuju) & 2 \\
\hline STS (sangat tidak setuju) & 1 \\
\hline
\end{tabular}

Setelah didapat skor masing-masing indicator, selanjutnya dicari skor keseluruhan indicator kemudian skor itu diubah menjadi nilai skala 100 dengan rumus :

$$
N \frac{S}{S \max } x 100
$$


$\mathrm{N}$ : nilai motivasi belajar

$S$ : skor motivasi belajar

S Max : skor maksimum motivasi belajar

Setelah diperoleh nilai dalam skala 100, maka ditentukan predikat dengan rentangan sebagai berikut:

Tabel 2. Rentan Nilai Motivasi Siswa

\begin{tabular}{ll}
\hline Nilai & Predikat \\
\hline $90 \leq \mathrm{N} \leq 100$ & Sangat baik \\
\hline $82 \leq \mathrm{N}<91$ & Baik \\
\hline $75 \leq \mathrm{N}<82$ & Cukup \\
\hline $\mathrm{N} \leq 75$ & Kurang \\
\hline
\end{tabular}

Analisis Hasil belajar Siswa

Hasil belajar diperoleh dari nilai ulangan post test pada akhir siklus . dari hasil test pada akhir siklus, dapat ditentukan nilai tertinggi, nilai terendah dan rata-ratanya .kategori hasil belajar disesuaikan dengan KKM (criteria ketuntasan minimal IPA yaitu 70). Dengan KKM tersebut dapat dibuat predikat sebagai berikut:

Tabel 3. Indikator Ketuntasan Hasil Belajar Siswa

\begin{tabular}{ll}
\hline Nilai & Predikat \\
\hline $90 \leq \mathrm{N} \leq 100$ & Sangat baik \\
\hline $82 \leq \mathrm{N}<91$ & Baik \\
\hline $70 \leq \mathrm{N}<82$ & Cukup \\
\hline $\mathrm{N} \leq 70$ & Kurang \\
\hline
\end{tabular}

\section{PEMBAHASAN}

\section{Deskripsi hasil penelitian}

Penelitian ini sudah dilakukan di SD Negeri Dendeng kecamatan Kupang Tengah Kabupaten Kupang. Waktu pelaksanaan pada bulan Juli s.d Agustus 2018 yang menjadi subjek penelitan adalah siswa kelas $\mathrm{V}$ tahun pelajaran 2018/2019 dengan jumlah siswa 21 orang, yang terdiri dari 10 laki-laki dan 11 perempuan. Penelitian ini dilakukan dengan 2 siklus dengan tahapan seperti, perencanaan, pelaksanaan, observasi dan refleksi.

\section{Siklus I}

Tabel 4. Hasil Belajar Siklus I

\begin{tabular}{cccc}
\hline Siklus & Rata-rata & Tuntas & Tidak tuntas \\
\hline $\mathrm{I}$ & 69,58 & $69,44 \%$ & $30,55 \%$ \\
\hline
\end{tabular}

Berdasarkan hasil evaluasi akhir siklus I pada tabel 4.2 terlihat 69,44\% siswa yang tuntas, sedangkan siswa yang tidak tuntas belajar 30,55\%. Dari hasil tersebut menunjukan bahwa pada siklus I siswa masih belum dikatakan tuntas belajar karena seorang siswa dikatakan tuntas belajar apabila telah mencapai 
skor $\geq 75$. Hasil belajar siswa siklus I melalui beberapa tahapan. Tahapantahapan penelitian tindakan kelas dalam siklus I sebagai berikut:

\section{Perencenaan Tindakan}

Penelitian ini menggunakan metode penelitian tindakan kelas (PTK). Penelitian dilaksanakan di kelas $\mathrm{V}$ yang berjumlah 21 siswa dan dilakukan dalam 2 siklus yang masing-masing siklus terdiri dari 2 kali pertemuan. Alokasi waktu untuk setiap pertemuan adalah 2 x 40 menit. Materi yang diajarkan pada siklus pertama adalah organ gerak pada hewan dengan menggunakan model pembelajaran Talking Stick Game Instrumen yang digunakan dalam penelitian ini meliputi instrumen pembelajaran dan instrumen pengambilan data. Instrumen yang disiapkan diantaranya sebagai berikut :

1 Menyiapkan RPP siklus I

2 Menyiapkan lembar kerja siswa siklus I

3 Menyiapkan soal pre test dan post test siklus I

4 Menyiapkan lembar observasi keaktifan siswa dan kusioner

\section{Pelaksanaan Tindakan}

Pada tahap pelaksanaan siklus I, guru melaksanakan proses pembelajaran pada materi organ gerak pada hewan dengan menggunkan model pembelajaran talking stick game.

1. Pertemuan pertama

a. Guru memulai pelajaran dengan salam dan doa

b. Memeriksa kehadiran siswa

c. Guru menyampaikan tujuan pembelajaran dan kompetensi yang ingin dicapai siswa dalam pembelajaran dan menjelaskan materi secara singkat tentang organ gerak pada hewan

d. Guru memberikan soal pretest untuk mengukur kemampuan awal siswa. Pertemuan kedua

a. Guru memulai pelajaran dengan salam dan doa

b. Memeriksa kehadiran siswa

c. Guru menyampaikan tujuan pembelajaran dan kompetensi yang ingin dicapai siswa dalam pembelajaran dan menjelaskan materi secara singkat tentang organ gerak pada hewan

d. Guru memberikan soal pretest untuk mengukur kemampuan awal siswa.

\section{Observasi Keaktifan Siswa}

Observasi siklus I difokuskan pada keaktifan siswa selama mengikuti kegiatan belajar mengajar saat diterapkan model pembelajaran talking stick game. Instrumen observasi berupa pertanyaan-pertanyaan dengan skala sikap yang digunakan untuk mengukur aktivitas belajar siswa. Aktivitas belajar siswa selama proses pembelajaran diamati dengan panduan lembar observasi keaktifan siswa dengan jumlah 9 pernyataan.

\section{Refleksi Tindakan}

Setiap siklus dilakukan refleksi tindakan yang didasarkan pada hasil observasi dan kusioner, tujuannya untuk memperbaiki proses belajar mengajar pada siklus berikutnya. Berdaskan hasil observasi studi awal (pre-test) sebelum 
pemberian tindakan rata-rata ketuntasan hanya 59 dan hasil observasi aktifitas belajar selama proses pemberian tindakan siklus I rata-rata 66,5, sedangkan rata-rata hasil tes siklus I dengan nilai 60,16 , sehingga hasil belajar siswa masih perlu diperbaiki dan ditingkatkan pada siklus II. Adapun kegiatan yang dilakukan pada siklus II ini sama seperti yang dilakukan pada siklus I.

Tabel 5. Hasil Test Akhir Siklus II

\begin{tabular}{cccc}
\hline Siklus & Rata-rata & Tuntas & Tidak tuntas \\
\hline II & 80,69 & $100 \%$ & - \\
\hline
\end{tabular}

Berdasarkan hasil evaluasi akhir siklus II pada tabel di atas terlihat $100 \%$ murid yang tuntas belajar. Dari hasil tersebut menunjukan adanya peningkatan hasil belajar pada siklus II. Karena seorang siswa dikatakan tuntas belajar bila telah mencapai skor $\geq 75$.

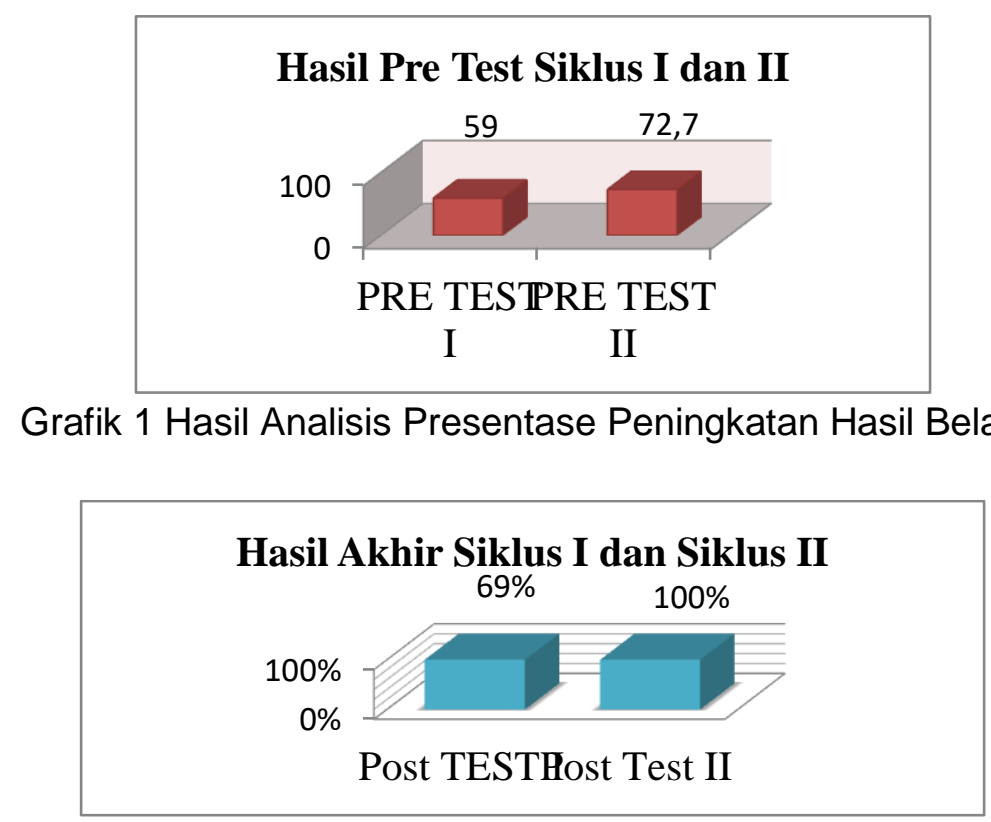

Grafik 2. Hasil akhir siklus I dan II Pada Pembelajaran talking stick game

Berdasarkan hasil belajar dari siklus I dan II dengan model pembelajaran talkin stick game siswa kelas $\mathrm{V}$ memiliki motivasi yang tinggi, ini dilihat berdasarkan angkat yang diberikan pada saat selesai pembelajaran rentang nilai angket pada siklus I rata-rata $83 \%$. Sedangkan pada siklus II rata-rata nilai angket di kelas $\mathrm{V} 95 \%$. Ini menunjukkan dengan model talking stick game ini sangat berpengaruh unutk meningkatkan motivasi siswa dalam melakukan pemebalajaran.

Sinaga (2016) menyatakan hasil belajar adalah kemampuan yang diperoleh anak setelah melalui kegiatan belajar. Hasil belajar akan tercermin dari kepribadian siswa yang berupa perubahan tingkah laku, yang terwujud setelah mengalami proses pembelajaran. Penilaian proses belajar merupakan upaya memberi nilai terhadap kegiatan belajar mengajar yang dilakukan oleh siswa dan guru dalam mencapai tujuan-tujuan pengajaran. Oleh sebab itu penilaian hasil 
dan proses belajar saling berkaitan satu sama lain sebab hasil merupakan akibat dari proses (Listiyadi, 2016)

pembelajaran. Hasil pengamatan menunjukan bahwa rata-rata skor observasi terhadap aktivitas siswa selama pembelajaran (pertemuan I dan pertemuan II) siklus II meningkat dengan rata-rata skor $85,5 \%$ dengan kriteria sangat baik. Hasil aktivitas guru dan siswa yang diperoleh dalam penelitian ini dipekuat oleh pendapat Ronawati (2016) yang menyatakan bahwa hasil diskusi kelompok dan cara pengambilan keputusan kelompok ternyata lebih efektif dibandingkan dengan metode ceramah dan pengajaran individual.

\section{SIMPULAN}

Berdasarkan hasil penelitian yang dipaparkan di atas maka peneliti bias menarik kesimpulan bahwa dengan menggunakan model talking stick game dapat meningkatkan motivasi dan hasil belajar siswa. Ini bias dilihat dari persentase setiap siklus pada saat proses pembelajaran. Pada siklus I rata-rata hasil belajar siswa $69,58 \%$ dan motivasi siswa berdasarkan angket yang diberikan adalah $89 \%$. Sedangkan pada siklus II rata-rata nilai hasil belajar siswa II 80,69 dan motivasi siswa berdasarkan angket yang diberikan adalah 95\%.

\section{DAFTAR PUSTAKA}

Budiningsih, C. A.2010 Belajar dan Pembelajaran. Jakarta: PT Rineka Cipta

Campbell. Jane. B. Reece. Lawrence G. Mitchell. 2003. Biologi. Jakarta: Erlangga

Dirmin dan Juarsih, C. 2014. Teori Belajar dan Prinsip-Prinsip Pembelajaran yang Mendidik. Jakarta : Rineka Cipta.

Gulo, W. 2002. Strategi Belajar Mengajar. Jakarta: Grasindo

Hamalik, O. 2015. Kurikulum dan Pembelajaran. Jakarta: PT Bumi Aksara

Hamdani. 2011. Strategi Belajar Mengajar. Bandung : Pustaka Setia.

Hardini, I. dan Puspita, D. (2012) Strategi Pembelajaran Terpadu. Yogyakarta: Familia

Kusmawati, R. Omegawati, W, H. 2010. PR Biologi Untuk SMA/MA Kelas $X / 2$ Kalten: Intan Pariwara.

Mansur, S. 2018. Aplikasi Asesmen Dalam Pembelajaran IPA di Kelas IV Sekolah Dasar Negeri Gelogor. Universitas Muhammadiyah Makasar. Jurnal Riset Pendidikan Dasar. 1 (1): 49-55. DOI: http://dx.doi.org/10.26618/jrpd.v1i1.1239

Mansur, S. 2018. Penerapan Model Pembelajaran Kooperatif Tipe STAD untuk Meningkatkan Motivasi dan Hasil Belajar pada Konsep Ekosistem di SMA Negeri 2 Maumere. STAI Darul Kamal NW Kembang kerang. Jurnal Al$\begin{array}{lllll}\text { Muta'aliyah. } & 1 & \text { (1): } & \text { 117-127. }\end{array}$ http://ejournal.kopertais4.or.id/sasambo/index.php/mutaaliyah 
Mansur, S (2018). Pengaruh Pendekatan Jelajah Alam Sekitar (JAS) Terhadap Hasil Belajar Siswa pada Materi Klasifikasi Mahluk Hidup di SMPK Binawirawan Maumere. BIOEDUSCIENCE: Jurnal Pendidikan Biologi Dan Sains, 2(1), 74-80. https://doi.org/10.29405/j.bes/2174-801314

Mansur S, Bare. Y. (2019) Meningkatkan Hasil Belajar Siswa pada Konsep Perubahan dan Pelestarian Lingkungan Hidup dengan Model Discovery Learning di SMAS Katolik ST Gabriel Maumere, BIOEDUSCIENCE: Jurnal Pendidikan Biologi dan Sains: Vol. 3 No. 2

Lutfi. 2007. Strategi Pembelajaran Biologi Teori, Praktik dan Penelitian. UNP Press: Padang

Nur, A., Kundera, I. N., Tangge, L. N. 2016. Pengaruh Model Pembelajaran Inkuiri dan Gaya Kognitif Terhadap Hasil Belajar Siswa Pada Mata pelajaran Biologi di Kelas Xi IPA MAN 2 Model Palu: Universitas Tadulako. Jurnal Mitra Sains. 4 (4): 57-66

Pitoyo, A. Nurdina, R, A. 2013. Biologi Untuk SMA/MA Kelas X. Sidoarjo : Mas media Buana Pustaka 